See Article page 597 in the August 2020 issue.

\section{Commentary: Thoracic surgery during the COVID-19 pandemic: Recommendations from China}

\author{
Chi-Fu Jeffrey Yang, MD
}

At the time of this writing, COVID-19 continues to surge in the United States, with more than 5.1 million cases and 165,000 deaths nationwide. ${ }^{1}$ Guidelines from the United States and Europe have been published to aid treatment decision making for thoracic cancers during the pandemic. ${ }^{2-15}$ Most of these guidelines have been written for hospitals and clinicians who still have the capacity to take care of cancer patients and have not been completely overwhelmed by COVID-19. These guidelines have generally recommended delaying surgery for select instances of early-stage disease and, for more advanced disease, proceeding with traditional curative-intent treatment consistent with pre-COVID standard-of-care recommendations. Consideration of other nonoperative treatments (eg, stereotactic ablative radiotherapy for lung cancer, endoscopic therapy for esophageal cancer) has been proposed as well. In "peak" stages of the epidemic, when hospital resources are severely strained, thoracic surgery is recommended only for patients with emergent clinical conditions, such as perforated esophageal cancers, which if left untreated would result in death within hours or days. ${ }^{2,15}$

Although these guidelines are useful, they have been written largely by American and European authors and speak to the American and European experience. To date, there have been very few recommendations from Asia. ${ }^{16-18}$ In the August issue of the Journal, Chen and colleagues, ${ }^{19}$ all expert thoracic surgeons from high-volume thoracic surgery centers across China, make several recommendations for the

\footnotetext{
From the Division of Thoracic Surgery, Department of Surgery, Massachusetts General Hospital, Boston, Mass.

Disclosure: The author reported no conflicts of interest.

The Journal policy requires editors and reviewers to disclose conflicts of interest and to decline handling or reviewing manuscripts for which they may have a conflict of interest. The editors and reviewers of this article have no conflicts of interest.

Received for publication July 12, 2020; revisions received July 12, 2020; accepted for publication July 13, 2020; available ahead of print July 16, 2020.

Address for reprints: Chi-Fu Jeffrey Yang, MD, Division of Thoracic Surgery, Department of Surgery, Massachusetts General Hospital, 55 Fruit St, Boston, MA 02114 (E-mail: cjyang@post.harvard.edu).

J Thorac Cardiovasc Surg 2020;160:e233-5

$0022-5223 / \$ 36.00$

Copyright (C) 2020 by The American Association for Thoracic Surgery

https://doi.org/10.1016/j.jtcvs.2020.07.040
}

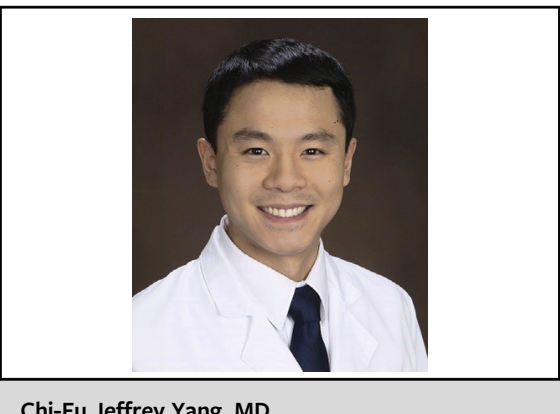

Chi-Fu Jeffrey Yang, MD

$$
\begin{aligned}
& \text { CENTRAL MESSAGE } \\
& \text { The article by Chen and col- } \\
& \text { leagues highlights lessons } \\
& \text { learned and recommendations } \\
& \text { from China regarding thoracic } \\
& \text { surgery during the COVID-19 } \\
& \text { pandemic. }
\end{aligned}
$$

treatment of thoracic surgical disease during the COVID-19 pandemic, in light of their experiences in China. The editorial is an important one, and the authors should be commended for their efforts.

Several of the author's recommendations are similar to those made by American and European authors. For example, the authors call for "the cessation of all thoracic surgeries for GGO-like lung adenocarcinoma with a diameter of $<30 \mathrm{~mm}$ during the COVID-19." No specification of time interval accompanies this recommendation, but other American and European groups have similarly commented on postponing surgery for nodules with groundglass opacities or lepidic adenocarcinomas for at least 3 to 6 months. $^{2,4,15}$

The authors also call for "enhancing preoperative induction treatment" in a manner similar to that proposed in the United States and Europe. The authors recommend that patients with operable stage IIIA N2 disease undergo induction therapy first, as opposed to surgery. This would allow patients to avoid an operation during potential COVID-19 hospitalization peaks. The standard of care in the United States and Europe is to give induction therapy first, followed by surgery for operable stage IIIA-N2 NSCLC. $^{20,21}$ In China, it can be common in centers to perform surgery first, followed by adjuvant chemotherapy for stage IIIA-N2 disease. $^{22,23}$ The authors' recommendation to proceed with induction therapy first, followed by surgery, is likely aimed at a Chinese audience, to urge more Chinese thoracic 
surgeons to consider the use of induction therapy during the pandemic.

Other practices in China differ from those at many US hospitals. Through correspondence with Dr Chen, I learned that most COVID patients are cared for in separate "COVID" or "infectious disease hospitals" as soon as the diagnosis is made. As Dr Chen wrote, "if tracheostomies and chest tubes are needed, ENT (tracheostomies) and thoracic surgeons (chest tubes) from other hospitals will be temporarily transferred to that hospital. And some infectious disease hospitals also have their own surgeons to take care of patients, such as at Ditan Hospital in Beijing."

Another key difference between China and the United States is the degree of testing and observation each patient receives before undergoing thoracic surgery. For patients who need surgery, presumably for more advanced disease, the authors recommend that "patients should be observed in a transitional ward for 2 weeks." The authors note that during this observational period, patients should be tested for COVID-19 by nasal swab 2 weeks before surgery and that within 1 week of surgery, patients should have a "chest CT for COVID-19 screening...C-reactive protein, procalcitonin, and influenza A and B examination." There is some variation as to how these recommendations are implemented. In correspondence, I learned from Dr Chen that at his institution, the practice is that "all patients from other parts of the country will be isolated in designated places [eg, hotels] for 2 weeks before they can visit our outpatient clinic. And before their admission [to the hospital for surgery], they will have throat swab test, antibody and blood test, as well as CT examination, to confirm they are COVID-19-negative."

High-volume centers in China also generally seem to be better-equipped and/or prioritize wearing protective personal equipment to a greater degree than their US counterparts. For example, Dr Chen noted that at his outpatient clinic, every provider wears an N95 respirator, isolation gown, gloves, and a face shield when interacting with patients, regardless of whether the patient is suspected to have COVID. In my own experience, and anecdotally from speaking with colleagues, this is not common practice in the United States. This past week in clinic, at my own institution, I was required to only wear a surgical mask.

The editorial by Chen and colleagues raises a number of points that are important for thoracic surgeons and oncologists treating lung and esophageal cancer patients to consider. There are additional questions that need to be discussed as well. For example, what if the pandemic continues with no abatement for another 1 to 2 years, how would practices change in that situation? How do we think about care for mesothelioma patients? Does definitive chemoradiation, which requires multiple outpatient visits, lead to less risk of exposure to COVID-19 to both patients and healthcare workers compared with surgery, which requires no outpatient visit (with telemedicine) and typically a single inpatient hospital stay?

In addition, it is worth noting that recommendations made by both the authors and by American and European groups are based principally on clinical expertise and opinion. More actual data to drive policy and practice are needed as well. To date, only a few studies have reported outcomes of patients with lung cancer and COVID-19, including 8 from China, ${ }^{24-31} 1$ from Denmark, ${ }^{32} 3$ from Italy, ${ }^{33-35} 2$ from Spain, ${ }^{36,37}$ and 2 from the United States. ${ }^{38,39}$ Most of these studies had only a few patients, and the largest involved only 22 patients. ${ }^{27}$ It will be critical for thoracic surgeons worldwide to actively report their experiences with COVID-19 patients and engage in dialogue and collaboration. Case reports are helpful, but more analyses of institutional data, national registries, and COVID-19 open-access data ${ }^{40}$ are needed. Meaningful multi-institutional collaborations enable studies with sufficient statistical power to facilitate such analyses. These analyses in turn can provide the groundwork for meaningful, guideline-changing recommendations. Such recommendations are desperately needed during this first COVID-19 wave, as well as for future pandemic waves.

\section{References}

1. Johns Hopkins University. COVID-19 Dashboard by the Center for Systems Science and Engineering (CSEE) at Johns Hopkins University (JHU); 2020. Available at: https://coronavirus.jhu.edu/map.html. Accessed August 12, 2020.

2. Thoracic Surgery Outcomes Research Network. COVID-19 guidance for triage of operations for thoracic malignancies: a consensus statement from thoracic surgery outcomes research network, the Society of Thoracic Surgeons and the American Association for Thoracic Surgery. J Thorac Cardiovasc Surg. 2020 [Epub ahead of print].

3. Mazzone PJ, Gould MK, Arenberg DA, Chen AC, Choi HK, Detterbeck FC, et al. Management of lung nodules and lung cancer screening during the COVID-19 pandemic: CHEST Expert Panel Report. Chest. 2020;158:406-15.

4. National Comprehensive Cancer Network (NCCN). Short-term recommendations for non-small cell lung cancer management during the COVID-19 pandemic. Available at: https://www.nccn.org/covid-19/pdf/COVID_NSCLC. pdf. Accessed June 10, 2020.

5. Singh AP, Berman AT, Marmarelis ME, Haas AR, Feigenberg SJ, Braun J, et al. Management of lung cancer during the COVID-19 pandemic. JCO Oncol Pract. May 26, 2020 [Epub ahead of print].

6. Kumar S, Chmura S, Robinson C, Werner-Wasik M, Edelman MJ, Moghanaki D, et al. Alternative multidisciplinary management options for locally advanced NSCLC during the coronavirus disease 2019 global pandemic. J Thorac Oncol. 2020;15:1137-46.

7. European Society for Medical Oncology (ESMO). ESMO management and treatment adapted recommendations in the COVID-19 era: Lung cancer. Available at: https://www.esmo.org/guidelines/cancer-patient-management-during-thecovid-19-pandemic/lung-cancer-in-the-covid-19-era. Accessed June 10, 2020.

8. Guckenberger M, Belka C, Bezjak A, Bradley J, Daly ME, DeRuysscher D, et al. Practice recommendations for lung cancer radiotherapy during the COVID-19 pandemic: an ESTRO-ASTRO consensus statement. Radiother Oncol. 2020; 146:223-9.

9. Banna G, Curioni-Fontecedro A, Friedlaender A, Addeo A. How we treat patients with lung cancer during the SARS-CoV-2 pandemic: primum non nocere. ESMO Open. 2020;5:e000765.

10. British Thoracic Society. Lung cancer and mesothelioma service guidance during the COVID-19 pandemic. Available at: https://www.brit-thoracic.org.uk/about-us/ covid-19-information-for-the-respiratory-community/. Accessed June 10, 2020.

11. Bilkhu R, Bille A. Elective lung cancer surgery in the COVID-19 era: how do we do it? Tumori. May 28, 2020 [Epub ahead of print]. 
12. Kapetanakis EI, Tomos IP, Karakatsani A, Koumarianou A, Tomos PI. Management of surgical lung cancer patients during the COVID-19 pandemic in the financially and resource strained Greek health care system. J Surg Oncol. May 23, 2020 [Epub ahead of print].

13. Thornton M, Reid D, Shelley B, Steven M. Management of the airway and lung isolation for thoracic surgery during the COVID-19 pandemic: recommendations for clinical practice endorsed by the Association for Cardiothoracic Anaesthesia and Critical Care and the Society for Cardiothoracic Surgery in Great Britain and Ireland. Anaesthesia. May 5, 2020 [Epub ahead of print].

14. Dingemans AC, Soo RA, Jazieh AR, Rice SJ, Kim YT, Teo LL, et al. Treatment guidance for patients with lung cancer during the coronavirus 2019 pandemic. $J$ Thorac Oncol. 2020;15:1119-36.

15. American College of Surgeons. COVID 19: Elective case triage guidelines for surgical care: thoracic cancer surgery. Available at: https://www.facs.org/-/ media/files/covid19/guidance_for_triage_of_nonemergent_surgical_procedures_ thoracic_cancer.ashx. Accessed June 10, 2020.

16. Xu Y, Liu H, Hu K, Wang M. Clinical recommendations on lung cancer management during the COVID-19 pandemic. Thorac Cancer. 2020;11:2067-74.

17. Li X, Liu M, Zhao Q, Liu R, Zhang H, Dong M, et al. Preliminary recommendations for lung surgery during COVID-19 epidemic period. Thorac Cancer. 2020; $11: 1372-4$.

18. Guo H, Chen X, Su C, Liu Y, Wang H, Sun C, et al. Challenges and countermeasures of thoracic oncology in the epidemic of COVID-19. Transl Lung Cancer Res. 2020;9:337-47.

19. Chen KN, Gao S, Lunxu L, He J, Jiang G, He J. Insights from China: improving thoracic surgery outcomes during the COVID-19 pandemic. J Thorac Cardiovasc Surg. 2020;160:597-600.

20. Vansteenkiste J, De Ruysscher D, Eberhardt WE, Lim E, Senan S, Felip E, et al. Early and locally advanced non-small-cell lung cancer (NSCLC): ESMO clinical practice guidelines for diagnosis, treatment and follow-up. Ann Oncol. 2013; 24(Suppl 6):vi89-98.

21. National Comprehensive Cancer Network (NCCN). Clinical Practice Guidelines in oncology: Non-small cell lung cancer (Version 3.2020). Available at: https:// www.nccn.org/professionals/physician gls/default.aspx. Accessed July 5, 2020.

22. Zheng D, Ye T, Hu H, Zhang Y, Sun Y, Xiang J, et al. Upfront surgery as first-line therapy in selected patients with stage IIIA non-small cell lung cancer. $J$ Thorac Cardiovasc Surg. 2018;155:1814-22.e4.

23. Zhong WZ, Wang Q, Mao WM, Xu ST, Wu L, Shen Y, et al. Gefitinib versus vinorelbine plus cisplatin as adjuvant treatment for stage II-IIIA (N1-N2) EGFRmutant NSCLC (ADJUVANT/CTONG1104): a randomised, open-label, phase 3 study. Lancet Oncol. 2018;19:139-48.

24. Tian S, Hu W, Niu L, Liu H, Xu H, Xiao SY. Pulmonary pathology of early-phase 2019 novel coronavirus (COVID-19) pneumonia in two patients with lung cancer. J Thorac Oncol. 2020;15:700-4.

25. Peng S, Huang L, Zhao B, Zhou S, Braithwaite I, Zhang N, et al. Clinical course of coronavirus disease 2019 in 11 patients after thoracic surgery and challenges in diagnosis. J Thorac Cardiovasc Surg. 2020;160:585-92.e2.
26. Huang J, Wang A, Kang G, Li D, Hu W. Clinical course of patients infected with severe acute respiratory syndrome coronavirus 2 soon after thoracoscopic lung surgery. J Thorac Cardiovasc Surg. 2020;160:e91-3.

27. Dai M, Liu D, Liu M, Zhou F, Li G, Chen Z, et al. Patients with cancer appear more vulnerable to SARS-CoV-2: a multicenter study during the COVID-19 outbreak. Cancer Discov. 2020;10:783-91.

28. Qu J, Yang R, Song L, Kamel IR. Atypical lung feature on chest CT in a lung adenocarcinoma cancer patient infected with COVID-19. Ann Oncol. 2020;31: 825-6.

29. Cai Y, Hao Z, Gao Y, Ping W, Wang Q, Peng S, et al. Coronavirus disease 2019 in the perioperative period of lung resection: a brief report from a single thoracic surgery department in Wuhan, People's Republic of China. J Thorac Oncol. 2020;15:1065-72.

30. Zhang H, Xie C, Huang Y. Treatment and outcome of a patient with lung cancer infected with severe acute respiratory syndrome coronavirus-2. J Thorac Oncol. 2020;15:e63-4.

31. Li YK, Peng S, Li LQ, Wang Q, Ping W, Zhang N, et al. Clinical and transmission characteristics of Covid-19: a retrospective study of 25 cases from a single thoracic surgery department. Curr Med Sci. 2020;40:295-300.

32. Suppli MH, Riisgaard de Blanck S, Elgaard T, Josipovic M, Pøhl M. Early appearance of coronavirus disease 2019 associated pulmonary infiltrates during daily radiotherapy imaging for lung cancer. J Thorac Oncol. 2020;15: 1081-4.

33. Bonomi L, Ghilardi L, Arnoldi E, Tondini CA, Bettini AC. A rapid fatal evolution of coronavirus disease-19 in a patient with advanced lung cancer with a long-time response to nivolumab. J Thorac Oncol. 2020;15:e83-5.

34. Leonetti A, Facchinetti F, Zielli T, Brianti E, Tiseo M. COVID-19 in lung cancer patients receiving ALK/ROS1 inhibitors. Eur J Cancer. 2020;132:122-4.

35. Trapani D, Marra A, Curigliano G. The experience on coronavirus disease 2019 and cancer from an oncology hub institution in Milan, Lombardy Region. Eur J Cancer. 2020;132:199-206.

36. Rogado J, Pangua C, Serrano-Montero G, Obispo B, Martín Marino A, PérezPérez M, et al. Covid-19 and lung cancer: a greater fatality rate? Lung Cancer. 2020;146:19-22.

37. Sereno M, Gutiérrez-Gutiérrez G, Sandoval C, Falagan S, Jimenez-Gordo AM, Merino M, et al. A favorable outcome of pneumonia COVID 19 in an advanced lung cancer patient with severe neutropenia: is immunosuppression a risk factor for SARS-COV2 infection? Lung Cancer. 2020;145:213-5.

38. Mehta V, Goel S, Kabarriti R, Cole D, Goldfinger M, Acuna-Villaorduna A, et al Case fatality rate of cancer patients with COVID-19 in a New York hospital system. Cancer Discov. 2020;10:935-41.

39. Luo J, Rizvi H, Egger JV, Preeshagul IR, Wolchok JD, Hellmann MD. Impact of PD-1 blockade on severity of COVID-19 in patients with lung cancers. Cancer Discov. 2020 [Epub ahead of print]

40. National Institutes of Health. Open-access data and computational resources to address COVID-19. Available at: https://datascience.nih.gov/covid-19-open-access-resources. Accessed June 10, 2020. 